\title{
Criminal couples. From 'madness shared by two' to the mental illness: A review of brutal crimes
}

\author{
Francesca Righi \\ Master in Criminologia e Scienze Strategiche, Sapienza Università di Roma; Grafologa forense in formazione, \\ Sapienza Università di Roma, Italy
}

\begin{abstract}
The criminal couple is an uncommon phenomenon, since criminals act alone or involving other individuals in a fortuitous manner. The murders committed in pairs represent a rather rare eventuality (it is estimated that in Italy they are about 5\%). At the base of this very particular dynamic there is the c.d. folie à deux, otherwise indicated in the psychiatric nosography as "Shared Psychotic Disorder" and ICD10 as "Induced Delusional Disorder". Described for the first time in 1887 by Lasègue and Falret, it is characterized by the appearance of a delirium in a subject called the Primary Case, shared by the induced subject. The delusional couple lives in close correlation and at the same time isolated from the social context, conditions that facilitate the influence of the incube, bearer of a more serious mental pathology, on the succubus not necessarily affected by a psychotic pathology, nor, by force coming from a criminal subculture. The succubus therefore welcomes the delirious ideas of the incube and makes them its own, giving life not to the simple sum of two individuals but to a quid novi represented by the couple, united by a very strong pathological dependence. This contribution aims to highlight, through the analysis of some famous homicidal couples, the recognition or otherwise of the perpetrators of crimes, a total or partial defect of mind and the consequent imputability not omitting considerations on the social reintegration of them; once the prison sentence has been expiated.
\end{abstract}

\section{RIASSUNTO}

La coppia criminale è un fenomeno poco comune, poiché i criminali agiscono da soli o coinvolgendo altri individui in maniera fortuita. Gli omicidi commessi in coppia rappresentano un'eventualità piuttosto rara (si stima che in Italia siano all'incirca il 5\%). Alla base di questa particolarissima dinamica vi è la c.d. folie à deux, altrimenti indicata nella nosografia psichiatrica come "Disturbo Psicotico Condiviso" e dall'ICD-10 come "Disturbo Delirante Indotto". Descritto per la prima volta nel 1887 da Lasègue e Falret, esso si caratterizza per la comparsa di un delirio in un soggetto detto Caso Primario, condiviso dal soggetto indotto. La coppia delirante vive in stretta correlazione e al contempo isolata dal contesto sociale, condizioni che facilitano l'influenza dell'incube, portatore di una patologia mentale più grave, sul succube non necessariamente affetto da una patologia psicotica, né, per forza proveniente da una subcultura criminale. Il succube dunque accoglie le idee deliranti dell'incube e le fa proprie, dando vita non alla semplice somma di due individui ma ad un quid novi rappresentato dalla coppia, unita da una dipendenza patologica fortissima. Tale contributo ha il fine di evidenziare attraverso l'analisi di alcune famose coppie omicide, il riconoscimento o meno, di un vizio totale o parziale di mente e la eventuale imputabilità, ivi incluse le considerazioni sul reinserimento sociale degli stessi, una volta espiata la pena detentiva.

\section{RESUMEN}

La pareja criminal es un fenómeno poco común, ya que los delincuentes actúan solos o involucran a otras personas de manera fortuita. Los asesinatos cometidos por parejas representan una eventualidad bastante rara (se estima que en Italia son alrededor del 5\%). En la base de esta dinámica tan particular está el c.d. folie à deux, de lo contrario se indica en la nosografía psiquiátrica como "Trastorno psicótico compartido" y ICD-10 como "Trastorno delirante inducido". Descrito por primera vez en 1887 por Lasègue y Falret, se caracteriza por la aparición de un delirio en un sujeto dicha caja primaria, compartido por el sujeto inducida. La pareja delirante vive en estrecha correlación, y al mismo tiempo aislado del contexto social, las condiciones que facilitan dell'incube gripe, el portador de una patología mental más grave, el súcubo no necesariamente sufre de un trastorno psicótico, o, necesariamente proveniente de una subcultura criminal. Por tanto, el súcubo da la bienvenida a las ideas del dell'incube delirante y hace su propia, creando no la simple suma de los dos individuos, sino a un novi quid representada por la pareja, unida por una adicción muy fuerte. Esta contribución se pretende destacar a través del análisis de algunos pares homicidas famosos, reconocimiento, o menos, de un defecto total o parcial de la mente y la eventual elegibilidad, incluyendo consideraciones sobre la reintegración social de la misma, una vez purgada la pena prisión.

\section{Introduction}

Criminal couples are an uncommon phenomenon, as criminals act alone or by involving other individuals in a fortuitous manner. Murders committed in pairs represent a rather rare possibility (it is estimated that in Italy they are about $5 \%$ ). At the base of this very particular dynamic there is the so-called folie à deux, otherwise indicated in the psychiatric nosography as "Shared Psychotic Disorder" and by the ICD-10 as "Induced Delusional Disorder". Described for the first time in 1887 by Lasègue and Falret, it is characterized by the appearance of a delirium in a subject called the Primary Case, shared by the subject Induced.

In 1909, Scipio Sighele published "La coppia criminale" (The Criminal Couple), a work that was fundamental for the study and understanding of this theme, since the theme had only been stud- 
ied by a few French authors. Acronyms divided the criminal couples into the following groups:

- The murderous lovers;

- The infanticidal couple;

- The family couple;

- The couple of friends.

The first type includes those who are bound by a love affair and it is precisely a lover who pushes the other to commit the crime, so the bond that pushes the incubes to submit to the succubus is the bond of a sexual nature; the second typology contemplates infanticide, a crime which, as Sighele said, is "a spontaneous, if not necessary, consequence of illicit love... one could almost say that the responsibility for the crime falls entirely on only one of the two individuals who make up the criminal couple, since the other only provides his unconscious and mechanical help"; the third typology foresees the development of a criminal suggestion between an individual of poor moral sense and a weaker one, within the family. According to the author, these types of murderous couples do not create an influence between the subjects, but a mutual encounter between two perverts who almost always kill for profit; the fourth is that of the couple of friends: "friendship is also a favourable condition for the development of a criminal suggestion, in the case in which one of the friends is a pervert and the other, psychologically, a weak one...". Sighele also dealt with degenerate couples (prostitutes and protectors or homosexual couples) and libericides. He based his statements on direct observation, finding in homicidal couples either an absolute predominance of one subject over the other, or a mutual concordance that comes from the encounter of two equally perverse wills. The phenomenon of suggestion was systematized by the French psychiatrist Charcot, according to whom it referred to a neuropathological model. In Italy, psychiatry initially adhered to the theoretical construct conceived by Charcot (Lombroso, Vizioli, Mosso) and then embraced the psychological theory that had imposed itself at the end of the nineteenth century. More recent contributions have re-proposed the issue of influence and the conditions that favour it, conditions that do not refer only to criminal couples, but also concern other areas of considerable criminal interest such as aging and the circumvention of incapacitated. The contemporary literature, starting from Sighele's monograph, has highlighted the peculiarities of shared madness, emphasizing that the delirious couple lives in close correlation and at the same time isolated from the social context, conditions that facilitate the influence of the incube, bearer of a more serious mental illness, on the succube not necessarily affected by a psychotic disease, nor, necessarily from a criminal subculture. The succube therefore welcomes the delirious ideas of the incube and makes them its own, giving life not simply to the sum of two individuals but to a quid novi represented by the couple, united by a very strong pathological dependence. Gralnick in 1949 divided four subgroups of madness into two:

- Sets madness, the most common: the symptoms of the dominant subject are adopted by the weakest and most suggestible subject;

- Simultaneous Madness: two intimate subjects, already predisposed to psychosis, develop symptoms at the same time, without anyone prevailing over the other,

- Communicated Madness: two predisposed subjects develop psychosis in an interval of time,

- Induced Madness: Two subjects with psychotic disorders adopt each other's delusional disorders.

Scholars have elaborated different theories to understand the mechanism behind the homicidal dynamics perpetrated in pairs. According to the criminologist Conan Wilson, ${ }^{1}$ man, like animals, also feels the need to assert his supremacy within the organised community, at the top of which are the dominant individuals and at the bottom of which are the submissive ones. He noted that the number of dominant subjects in proportion to the population is always the same, one in twenty, for all species of social animals, including man. Wilson pointed out that this small group of the population under certain conditions, for example in the event of overcrowding, reacted in an exaggerated and violent manner. Conditions of overcrowding and poverty inevitably lead to the development of crime, but do not provide an exhaustive explanation of the phenomenon of the murderous couple or serial killers. Wilson explained the causes of unmotivated or serial homicide by referring to the theory of the hierarchy of human needs developed by Maslow in the 1930s: they are represented by a pyramid at the base of which are those physiological, elementary, up to those placed at the top of the pyramid, also called meta-needs. In this last stage man aspires to self-realization, that is, "to be what you would like to be". Through this interpretation it is easy to understand how in rich societies there is the phenomenon of serial killers, in those same societies in which the primary needs are satisfied but man must satisfy others such as the need for security, belonging, esteem and self-realization. The need for self-esteem is the main motive for serial killings: the Serial Killer feels inadequate and vents his frustration by killing, defying the social rules to assert his power so kills to meet his need to "feel someone", to affirm his self, and it is precisely this need that forces him to coerce killing several times, because killing is a necessity, an uncontrollable need. ${ }^{2}$

Maslow also explained why murderous couples consisting of a man and a woman are formed. Through interviews with female students about their sex lives, he was able to ascertain the link between the conception of sex and the degree of dominance:

women with a high degree of dominance were promiscuous and oriented towards the experimentation of even extreme sexual practices,

- women of average dominance looked more at the romantic side of sex and put the stability of the relationship before the sexual component,

- women with low dominance conceived sexual activity only as aimed at reproduction.

The women of all three categories (high, medium or low dominance), chose a man with a dominance slightly higher than their own but belonging to the same group. The most common case is that of

1 See Wilson C., A Criminal History of Mankind (Storia Criminale del Genere Umano-Storia mondiale dell'omicidio, del terrorismo e della rapina a mano armata - Newton Compton Editore). The scholar, already in the summer of 1959, had noticed that the rate of crime in the world was constantly growing and that the type of crime varied from country to country. "The French and Italians are inclined to "crime passionel", while the Germans are inclined to that of a sadistic nature, the English to the carefully planned crime, often against a spouse or lover and the Americans to that rather random and unpremeditated. The various types of crime vary from century to century, even from decade to decade." To explain the causes of serial and unfounded homicide, Wilson pointed out that crime had changed in relation to the development of human needs, according to the hierarchy proposed by Maslow: from crimes committed for the purpose of survival in the eighteenth century, (satisfaction of the first two needs of Maslow) to those committed after the Second World War and motivated by the need for self-esteem of the killer, who feels rejected by society.

2 See, Wilson C., "What I noticed in 1959 was therefore a phase of transition to a new hierarchical level: that of self-esteem crime. From then on, the number of crimes committed by people convinced that society was to blame for not having been able to guarantee them dignity, justice and recognition of individuality grew, thus inducing them to consider their crime as a sort of legitimate protest". 
a couple made up of a dominant man and a submissive woman, but couples made up of two men and two women united by a bond that can be familiar, friendly or erotic are also possible. The man/woman couples represent $35 \%$ of the total and the link between the two subjects is of a sexual nature. The characteristics of the man/woman pair according to Furio (2001) are shown below: ${ }^{3}$

- are usually lovers and in most cases, the nature of the crimes is sexual;

- than the man and woman she kills alone;

- the woman meets her partner at a young age, between the ages of twenty and twenty-five and is emotionally vulnerable;

- the woman tries to indulge the man and therefore agrees to participate in the crimes to support the fantasies of the partner;

- as time goes by, the woman rejects her gregarious position and often confesses to the crimes committed.

In some cases, however, the woman can be the dominant figure, as in the couple Fernandez-Beck, known as "murderers of lonely hearts" who acted in the United States in the fifties, killing about twenty women after having cheated them. The subject of this work are three criminal couples whose heinous crimes shook public opinion in Italy, in the 70s and in 2001, which have similarities in the criminodynamics and in the motivation that led them to commit these crimes.

\section{The Graneris-Badini case: The murderous couple for money}

\section{Place of crime: Vercelli}

\section{Date: 1973}

\section{Victims: 5}

Doretta Graneris was the firstborn of a bourgeois family from Vercelli. Troubled and restless, she met Guido Badini at a New Year's party in 1973. The two boys immediately started dating but the relationship was not well seen by her family, because Guido did not have a permanent job but cultivated a passion for cars and weapons. For the girl having a partner was extremely rewarding as she had struggled throughout her adolescence against a sense of inferiority and inadequacy. She had developed a deep resentment and hostility towards her parents, because she considered them oppressive and not very open-minded. To escape his parents' control, he left his family home and went to live with Guido. Their economic conditions were precarious because Guido was unemployed. In this context, the idea of killing Doretta's family matured in order to take possession of the patrimony that her parents had accumulated through a life of honest work. On the evening of November 13, 1973, under the pretext of discussing some of the details of their marriage, the two young men were welcomed by Doretta's family, which was gathered in front of the television, and they opened fire killing her parents, her maternal grandparents and her little brother. The two of them escaped. Once the massacre was discovered, the girl was informed of the incident, but reacted with a coldness that turned out to be suspicious. Taken to the barracks for interrogation, she provided conflicting versions until she and her boyfriend began to accuse each other. They never showed signs of repentance. Graneris and Badini were sentenced to life imprisonment because they were considered capa-

3 Cfr., Furio J., A comparative study of collaborative criminals, Algora Publishing, New York, 2001. ble of understanding and will. Doretta got parole in 1992. Between the two, the dominant element was Guido, a cold, astute and manipulative man whose real objective was to easily obtain the economic possibility through which to satisfy his obsessions with greatness. Doretta, insecure and introverted, was gratified by the bond with Guido and thanks to his support reinforced the feelings of hatred towards his family, so the basis of the crime concurred common reasons, namely greed and personal reasons, or the hatred that Doretta had towards his parents. Graneris graduated in architecture while serving her prison sentence and in 1992 she was granted conditional release. This act of clemency aroused much controversy in public opinion and the case returned to the fore in 2001, due to the similarities with the crime of Novi Ligure.

\section{Devilish lovers: The pair Dancers-Pan}

\section{Place of crime: Turin}

Date: 1972

\section{Victims: 1}

The event took place in Turin in 1972. Franca Ballerini and Paolo Pan were accused of having killed her husband, Fulvio Magliacane, to live their passion freely. The two had an affair even before the woman's marriage, which was interrupted when Pan entered prison.

The life of the latter was marked early by deviance and transgression that led him to enter the circuit of organized crime. Once he was free again, the two of them started seeing each other again on a regular basis. Franca denounced her husband's disappearance and pointed out that he had run off with another woman. A very different picture was soon drawn: an indirect witness told the Carabinieri that a acquaintance of his, Tarcisio Pan, Paolo's brother, had helped the latter to hide the body of Franca's husband, Paolo's lover and that she herself was responsible for the murder. They took each other to prison and accused each other. The two lovers have common personological traits: coldness and emotional detachment from the victim, seductive and manipulative abilities. It is an equal and parallel pair, where there is no dominance of any part. The two, therefore, had been useful to each other to overcome the mutual existential voids. They were judged fully capable of understanding and wanting but only Pan was sentenced to life imprisonment. Graced later, he returned to his cell for drug trafficking while Franca was acquitted for not having committed the crime.

They killed for convenience, because killing was useful to their mutually exploitative relationship. In this couple, therefore, there is neither dominance of one side over the other nor induction: it is a meeting of lives that say nothing about the reasons for a crime that has remained unexplained.

\section{Teenage murderers: The crime of Novi Ligure}

\section{Location: Novi Ligure}

Date: 21 February 2001

\section{Victims: 2}

In February 2001 in Novi Ligure, Susy Cassini, her son Gianluca, was stabbed to death in their small villa. The perpetrators of the atrocious crime were the woman's daughter, Erika De Nardo, 16 years old, and her boyfriend, Omar Favaro, 17 years old. Initially they planned to kill only the mother, then they decided to kill her lit- 
tle brother as a dangerous witness. Erika had a deep hatred for her mother because she felt controlled and judged and did not tolerate the woman's observations, even contrary to her story with Omar, a boy from a modest family. She was jealous of her brother who represented for her mother the model, polite, respectful son who attended school with excellent profit. Erika represented the classic irosa teenager, gloomy and protesting who did not accept rules. When he met Omar, he became his whole world: they spent the afternoons together having compulsive sex and occasionally consuming drugs, isolating themselves from their peers. Erika was the dominant element of the couple that kept Omar connected to itself through sex, concretely implementing a form of possession of the other, as if it were an object. After the commission of the crime Erika wants to wait for her father's return to kill him too but Omar refuses and leaves. Shortly afterwards the girl leaves the house with her bloody clothes invoking help. He will report to the police about a robbery attempt by two Albanians that ended tragically.

This statement was not supported by the facts, there had been no break-in, the weapons used to kill were kitchen knives and no robbery had been committed. The truth came out thanks to the bugs placed in the barracks that record the dialogue between the two, who planned to escape if they were discovered. The hidden cameras also took back the young woman who mimicked the gesture of inflicting a stab and asked her boyfriend if he had fun killing.

Erika and Omar were declared fully capable of understanding and willing and condemned by the Juvenile Court of Turin to 16 and 14 years imprisonment respectively. The sentences were confirmed both in the Appeal and in the Cassation.

One possible explanation for such a heinous crime lies in the personality type of the girl: she felt the need to satisfy her desire for well-being and fun without anyone setting limits to her will: she wanted to be free to live her life and history with Omar without any obstacle and her mother represented a huge obstacle that had to be eliminated. Erika has never shown repentance for what she has done and the judges defined the premeditation of the lucid and utilitarian crime, carried out with the full ability to understand and want. The basis of all this is the narcissistic personality of the girl, her request for affection that in the relationship with Omar becomes possession and willingness to dominate. Omar was introverted and insecure, dependent on his mother and when he meets Erika he becomes transgressive and aggressive and submits to her will. The reports revealed personality disorders (borderline disorder with narcissistic traits for Erika and personality dependent disorder for Omar), but not serious enough to affect the defendants' ability to understand and will. In conclusion, in the absence of a frank mental pathology, it can be said that the cause of the atrocious crime was "the lack of evolution of moral and emotional standards that led to serious deficiencies in affective-relational level with the consequent anaesthetization of feelings and emotionality. ${ }^{4}$

\section{Ability to understand and want and personality disorders of the accused}

Article 85 of the Penal Code states: "No one shall be punished for an act provided for by law as a criminal offence if, at the time

4 Interview with Professor Vincenzo Mastronardi, psychiatrist and clinical criminologist, former professor of forensic psychopathology Sapienza University of Rome, cit. it was committed, it was not attributable. "It's down to the person who has the ability to understand and want."

It is therefore necessary the ability to understand, that is, to understand the value or disvalue of one's own behaviour and its effect on the surrounding reality, and that of wanting, that is, the willingness to implement certain behaviours, in order to choose how to behave in view of achieving a certain purpose.

The legislator provides for the total vice of the mind, for which the subject who is affected is not attributable (Article 88 of the Criminal Code), or partial (Article 89 of the Criminal Code), which greatly diminishes the ability to understand and want without, however, excluding it, for which the penalty is reduced. The code also states that the so-called emotional and passionate states do not exclude or diminish imputability (art. 90). The code did not foresee (and does not foresee) the so-called personality disorders, for which a normative void was created in reference to all those situations in which the cognitive abilities were intact but the affective and relational fields were compromised.

\section{Considerations on imputability}

The difficulty with imputability was to assess certain situations that were not covered by the law, such as personality disorders that were not part of the group of psychiatric disorders. The gap was overcome with the Judgment of the Supreme Court of the United Criminal Sections 8 March 2005 n. 9163 which established that "personality disorders may constitute a suitable cause to exclude or greatly diminish, autonomously and specifically, the ability to understand and will of the subject acting for the purposes of Articles 88 and 89 of the Criminal Code, provided that they are of such consistency, intensity, relevance and gravity as to concretely affect the same; however, other character anomalies or emotional and passionate states, which do not have the aforementioned connotations of incisiveness on the ability of self-determination of the subject acting, are not relevant for the purposes of imputability.

The Court specified that there must be an aetiological link between the offence and the mental disorder which makes it possible to consider the offence to be causally linked to the mental disorder. From what emerged from this brief examination, it can be said that it is not possible to reduce the functioning of homicidal couples within a pre-established scheme, since each one has its own characteristics and motivations that led to the crime, but common elements can be found. In the couple Ballerini-Pan there is neither induction nor suggestion but a simple life encounter between two subjects that tells us nothing about the motive of a murder shrouded in mystery.

The common denominator between the couple GranerisBadini and De Nardo-Favaro, is the presence of a personality disorder that severely compromises the affective-relational sphere but not the cognitive abilities. The aim of living for these subjects is the satisfaction of their needs, material well-being and fun.

The emotional sphere is severely lacking, as demonstrated by the lack of guilt and repentance for the crimes committed. This anaffectivity and inability to relate is therefore born within the family and Erika and Doretta are proof of this.

At the base of the two girls' conflict with their parents, in addition to personality disorders, there is a lack of real communication and sharing between family members that has fuelled the sense of emptiness and misunderstanding, until the meeting with the partner who has fuelled and strengthened the idea of killing their relatives, until you reach the extreme epilogue. Forensic psychopathology has clarified, as far as possible, the functioning of the mind of a 
killer and what are the causes that trigger homicidal fury, through extensive literature in this regard, while more recent national and international studies of legal psychology that apply the institute of recidivism to perpetrators of violent crimes.

\section{Notes on the assessment of the risk of recidivism by perpetrators of violent crimes}

The evaluation of the Risk Assessment by the perpetrators of violent crimes is an essential function of the criminal justice system whose objective, from a forensic-psychological perspective, is to provide the judiciary and the penitentiary system with specific, suitable and scientifically validated tools on the basis of which to formulate the risk of recidivism.

The guidelines on this subject are still scarce and not widespread, although the operational practice and literature of AngloSaxon countries such as the USA, Great Britain and Canada provide good examples in this regard. Several theoretical and methodological models have been prepared, based on risk factor assessment scales, tools capable of providing psychometric measurements of the subject's personality and statistical predictive measures of the risk of recidivism.

Research in this area has focused on sexual offences through the use of interview and evaluation protocols such as STABLE 2000 , which is based on the previous SONAR.

These tools, through the analysis of static, dynamic and acute factors, allow a prediction of the possibility of recidivism depending on the results such as high, medium or low.

Static risk factors can be defined as relatively immutable variables, which reflect the personal and criminal background of the offender, e.g. age, number and type of previous offences, type of victims and give indications on the long-term risk status (baseline risk status). Dynamic risk factors or criminal needs are those that are susceptible to change, and once changed they indicate the possibility of change in the probability of recidivism. They indicate that the possibility of risk is not static but variable in relation to the psychological state of the offender and his socio-relational situation. The observation of these factors makes it possible to determine the probability that the subject has to incur in a recurrence within a period of six to twelve months after the evaluation. These factors are divided into stable and acute factors. For example, those that concern the ability to control oneself, affective relationships, adherence to treatment, everything that can be considered as a relatively durable characteristic of the personality of the offender are stable. Acute factors, on the other hand, have been that they change rapidly, for example the use of inhibitors such as alcohol and substances, or the mood. These states tend to get worse shortly before the offender commits a new crime.

Volpini and De Leo, legal psychologists, proposed an adaptation of the tools designed to assess the risk of recidivism of sex offenders to the perpetrators of homicides, applicable also to murderers in pairs, through a clinical-anamnestic interview on the personal history of the murderer and his physical, psychological and social development.

The interview is therefore of fundamental importance for the purpose of prognostic judgement on recidivism, both during the execution of the sentence, in order to identify the most suitable treatment path for the offender, and for the supervisory magistracy regarding the granting of benefits or alternative measures to detention.

It is to be hoped that research will continue to offer scientifically validated tools and methods that can be used by legal practi- tioners for social security purposes, so that detention can actually be used for recovery purposes and social reintegration is also possible for those who have committed homicides, reducing the percentage of recidivism to a minimum, so that prison is not just a mere place of coercion but has a re-educational purpose in accordance with the provisions of Article 27 of the Constitution.

\section{Concluding remarks}

Criminal couples are an extremely rare phenomenon with very specific characteristics. Psychiatry and criminology try to investigate the motivations that lead two individuals to join together to create a new entity, which needs the contribution of both subjects to exist. It has been amply demonstrated by the studies conducted on this phenomenon that the bond of a sexual nature is the most powerful to exert domination over the other. Couples of lovers kill for the most disparate reasons: for love, for hatred, for money, for perversion and sadism, for the desire to escape from a reality that has become intolerable.

The dismay that arises in the social community at the committing of such heinous crimes lies in the impossibility of conceiving why. Why do apparently normal subjects come this far? Why do they often turn their murderous fury against their families? Can they be rehabilitated?

There is no certain answer for all cases, but progress in psychiatry, psychology and forensic science has contributed to a better understanding of the complex dynamics underlying this phenomenon. The crucial point is to reconcile the punitive pretence of justice and society with the current hypothesis of prison treatment, and if there were the conditions, of reintegration into the community of perpetrators of crimes as brutal as incomprehensible, because behind the "monsters" there are only men.

\section{References}

Bandini et al. (2004) Ccriminologia. Il contributo della ricerca alla conoscenza del crimine e della reazione sociale, Giuffrè, Milano.

Callieri B., "I comportamenti indotti. Considerazioni di uno psicopatologo", in: Criminologia, Psichiatria Forense e Psicologia Giudiziaria, Delfino, Roma, 1996.

Callieri B., Flick G.M., "I comportamenti indotti". Aspetti psichiatrici e giuridici", Rivista Italiana di Diritto e Procedura Penale, N.S., XVI/4,800-817, 1973.

Coda S., "Coppie criminali" Amarsi, vivere, uccidere, Centro Scientifico Editore, Torino, 2001.

De Luca R., Anatomia del serial killer, Giuffrè, Milano, 1998.

Fornari U., Trattato di psichiatria forense, Utet, Torino, 1997.

Furio J., Team Killers. A comparative study of collaborative criminals, Algora Publishing, New York, 2001.

Gaddi D. (1999) cit. in Leonardi F., "Le misure alternative alla detenzione tra reinserimento sociale e abbattimento della recidiva", Rassegna Penitenziaria e Criminologica, n. 2, 2007, pag. 17.

Gulotta G., Elementi di psicologia giuridica e di diritto psicologico, Giuffrè, Milano, 2000.

ICD-10, Classification of Mental and Behavioral Disorders: clinical descriptions and diagnostic guidelines, Ed. italiana a cura di D. Kemali, M.May, F.Catapano, S.Lobrace, L. Magliano, Masson, Milano, 1992. 
Lasegue C., Falret J., "La folie à deux" (ou folie communiqueè, Annales Medico-Psycologique, vol. 18,1877.

Marini, G., Incapaci (circonvenzione di), in Dig. pen., VI, Torino, 1992, 308 ss.

Maslow A. H., Verso una psicologia dell'essere, Roma, AstrolabioUbaldini, 1971

Maslow A. H., Teoria della motivazione umana, Milano, Pirelli, 1973.

Maslow A. H., Motivazione e personalità, Roma, Armando, 1973.

Mastronardi V., Manuale per operatori e psicopatologi forensi, Giuffrè, Milano 2012.

Mastronardi V., de luca R., I serial killer. Chi sono e cosa pensano? Come e perché uccidono? La riabilitazione è possibile? Newton \&Compton Editori, Roma, 2005.

Mastronardi V., L M., Ventura N. Imputabilità, coscienza morale e psicopatologia. Profili comparatisti internazionali", Riv Psichiatr, 47(4 Suppl.1), 2012, pp.17s-25s.
Palermo G. B., Mastronardi V., Il profilo criminologico, Dalla scena del crimine ai profili socio-psicologici, Giuffrè, Milano, 2005.

Picozzi M., Piccoli omicidi la (stra)ordinaria violenza degli adolescenti, Monti, 2002.

Sighele S., La coppia criminale, Fratelli Bocca, Torino, 1909, (III ed.).

Simon R.I, I buoni lo sognano i cattivi lo fanno: psicopatici, stupratori, serial killer, Raffaello Cortina editore, 2005.

Volpini L., Mannello T., De Leo G., "La valutazione del rischio di recidiva da parte degli autori di reato: una proposta", Rassegna Penitenziaria e Criminologica, n.1, 2008, pp.147-161.

Wilson C., (1990) A criminal history of mankind. New York: Carrol \& Graf, 1990

Wilson C., Seaman D., Il libro nero dei serial killer, Newton Compton Editori, 2005.

Wilson C., Storia Criminale del Genere Umano-Storia mondiale dell'omicidio, del terrorismo e della rapina a mano armata. Newton Compton Editori, 2008.
Correspondence: Francesca Righi.

E-mail: francesca.righi2@gmail.com

Key words: Criminal couples; folie à deux; shared psychotic disorder; induced delusional disorder.

Parole chiave: Coppia criminale; folie à deux; disturbo psicotico condiviso; disturbo delirante indotto.

Palabras clave: Pareja criminal; folie à deux; trastorno psicótico compartido; trastorno delirante inducido.

Received for publication: 27 August 2018

Revision received: 15 September 2018.

Accepted for publication: 5 November 2018

This article is distributed under the terms of the Creative Commons Attribution Noncommercial License (by-nc 4.0) which permits any noncommercial use, distribution, and reproduction in any medium, provided the original author(s) and source are credited.

(C) Copyright F. Righi, 2018

Licensee PAGEPress, Italy

Rivista di Psicopatologia Forense, Medicina Legale, Criminologia 2018: $23: 39$

doi:10.4081/psyco.2018.39 